\title{
Human rights and divine justice
}

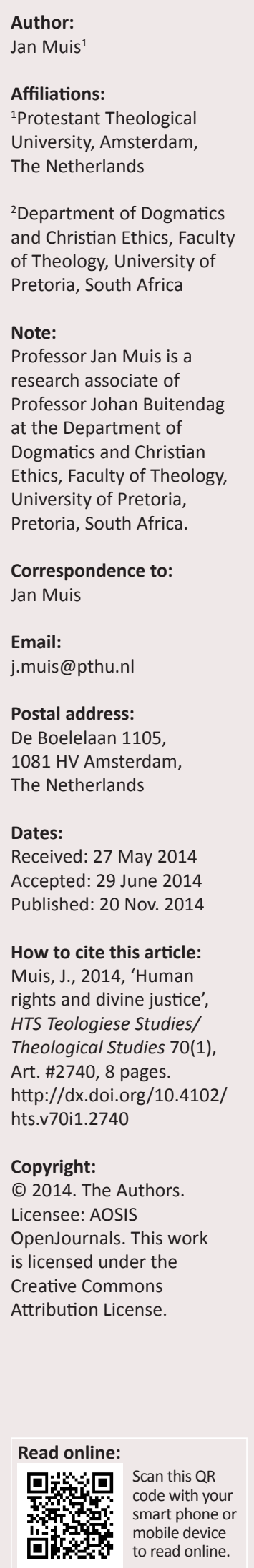

This article discusses the view of the Leiden professor Paul Cliteur that human rights are essentially secular and require rejection of God's will as source of moral authority. Firstly, it analyses Cliteur's reception of Kant and his claim that an exclusively anthropological grounding of human rights is the only possible one. Next, it investigates Nicholas Wolterstorff's criticism of Kant's grounding of human dignity in the rational capacity of mankind and his theistic grounding of human rights in God's love by the mediating concept of human worth. Although Wolterstorff rightly believes that God's special relationship with human beings is ultimately the best ground for human rights, his understandings of God's love and of human worth appear to be problematic. Finally, the article explores the possibility to ground human rights directly in God's justice by construing creation, the giving of the Ten Commandments and the justification of the sinner as central divine acts of justice in which God has given human rights to all human beings.

\section{Problems with human rights}

Talk about human rights is everywhere in modern society. Since the General Assembly of the United Nations proclaimed the 'Universal Declaration of Human Rights' in 1948, human rights have become central to moral and political discourse. They have become a cornerstone of international law. They have supported oppressed groups and individuals and justified their political struggles for liberation and emancipation. In modern western societies, people make their political claims on the basis of the rights they assume to possess. This pervasive talk about human rights signals a profound shift in our understanding of the foundations of morality. Generally speaking, in pre-modern times an action was considered morally good if it was willed by God. Nowadays, an action is morally good if it corresponds to someone's right.

Yet, the notion of human rights is not self-evident. It is a matter of dispute and controversy. It raises profound questions. To start with, it can be doubted whether there are universal human rights at all. Some argue that people have only rights in particular communities, traditions and practices. Legal rights are conferred on individuals and groups by law and custom and they differ in different countries. Moral rights only exist in specific moralities. It is concluded from this that there are no natural human rights, that is, universal human rights that have not been conferred on human beings by a legal system or a moral tradition (MacIntyre [1981] 1984:69-70; Mooij 2012:5354). In addition, MacIntyre has argued that talk about rights is a modern phenomenon. Rights were introduced in order to ground a new moral framework after the classical and Christian tradition of virtue ethics had collapsed (MacIntyre [1981] 1984:68).

Another reason for scepticism about human rights is that they seem to presuppose an autonomous individual, a being that is not essentially embedded in a society, a being that can be completely himself without others (Taylor 2007:392,447). There is a suspicion that human rights express a non-relational anthropology. This seems especially true for the classical rights of life, freedom, property and security that were formulated in the Declaration of Independence of the Second Continental Congress of the United States of America in 1776 and in the Déclaration des droits de l'homme et du citoyen of the National Assembly of the French People in 1789. The individualistic character of these rights is the reason why Marx and Marxist thinkers have always been suspicious about human rights; they seemed not only to protect the privileges of the bourgeoisie against the king and his state, but also against the working classes. These days, similar objections against the individualism of human rights are made by communitarian thinkers.

A third point of controversy about human rights is the claim that they are essentially secular because they proclaim human autonomy as the ultimate source of moral authority instead of the will of God (Cliteur 2013:33, 41). Jonathan Israels argues that the development of human rights is a fruit of secularisation (discussed in Gregory 2012:227). He claims that the best foundation 
for modern human rights is given by radical Enlightenment thinkers. In his view, human rights can only flourish in a secular state. If this is correct, Christian believers are faced with a dilemma. If they want to accept and defend human rights they have to reject God as the ultimate source of moral authority. If, on the other hand, they believe in God as ultimate moral authority, they cannot really accept and defend human rights. The view that human rights are essentially secular can be found both with Christians who reject human rights and with secularists who defend human rights. In the 19th century Pope Pius IX fulminated against modern human rights in his Syllabus errorum (1864). In the early 20th century, Protestant theologians were very critical about human rights (cf. Schenderling 2010:7-8, 10-11). In our times, Muslims are sometimes sceptical about human rights because they think these are at odds with their religion (Cliteur 2009).

The view that acceptance of human rights requires a rejection of the divine will as ultimate moral authority, is advocated in the Dutch public debate by the Leiden professor of law Paul Cliteur. Cliteur argues that human rights are essentially an Enlightenment project which can only be successfully maintained in our global, multicultural society by rejecting the so-called 'divine command theory', the view that God's will determines what is morally good or bad (Cliteur 2007). Cliteur illustrates the progress that has been made in this Enlightenment project of human rights by comparing the Declaration of Independence of the United States of America (1776) with the Universal Declaration of Human Rights of the United Nations (1948). In the former declaration, belief in the Creator is foundational for human rights, in the latter, human rights are exclusively grounded in human dignity (Cliteur 2004:157-159; cf. Wolterstorff 2008:312-313). The notion of human dignity is central to Kant's moral philosophy. 'The Universal Declaration of Human Rights can be regarded as the apotheosis of Kant's approach' (Cliteur 2004:164). In Cliteur's view, we have a real dilemma here; we must choose between human rights based on human dignity and divine authority.

There is still another reason why in the near future human rights may become less plausible. There can only be human rights if human beings exist and if their existence is legitimate. The existence of human beings as essentially different from other living beings such as animals, and the legitimacy of human existence on planet earth are becoming less obvious for many people than they have been in earlier centuries. Evolutionary biology raises the question whether there really is a human species that can be distinguished from other species. In addition, philosophical deconstruction of the human subject, as can be found in Foucault for instance, undermines the notion of human dignity and human worth (discussed in Brague 2013:68-72). These issues may seem rather theoretical and philosophical, but they have important corollaries for our view on human rights. If there are no human beings, there can be no human rights either (Gregory 2012:225-226). If we want to base our moral convictions and societal and political practices on human rights, we must also maintain that human beings are not just a biological variety among animals and that the notion of humanity is more than a misplaced philosophical construction.

In this article, I want to reflect on the third one of these problems, the rather urgent question of whether human rights are essentially secular.

If Paul Cliteur is right that human rights must be grounded without any reference to God and his will, Christian believers have a serious problem indeed. Then they can only accept and defend human rights by ignoring God and his will. Cliteur's claim is a serious challenge to the Christian faith and to Christian theology that must be responded to. Therefore, in this article, I look for a response to this claim.

\section{Are there human rights?}

Before I respond to Cliteur, I must address briefly the issue whether there really are human rights that are universally valid. This question is so crucial to our topic that it cannot be ignored. When we reflect on the universal validity of human rights, we should distinguish between legal rights and moral rights. In every society with some kind of legal system, rights exist that have been conferred upon individuals and groups by legislation and jurisdiction. These are legal rights. Even if there is no legislation, in every community, people follow certain rules of behaviour. Suppose you live in a society in which it is not legally forbidden to hurt or to kill someone else. Would this mean that you have the right to hurt or to kill? I think you would not. Why is this? Because other people have the right not to be hurt or killed by you, even if it is not legally forbidden to hurt or to kill. The right not to be hurt or killed in normal circumstances may not be a legal right; it still is a moral right. Without any rule for behaviour, there would be no society but only anarchy. Because rules of behaviour imply rights, there is no society without rights, legal rights or moral rights. Moral rights often coincide with legal rights, but not always. People can have moral rights that have not been legalised by legislation and jurisdiction. The notion of a moral right is conceptually connected with the notion of wrong. If I hurt you or kill you, you are wronged. Hurting or killing you is wrong because it violates your right not to be hurt and not to be killed. When you are wronged, a right of yours is violated (Wolterstorff 2008:293-295). If there would be no rights, there would be no wrong either. Therefore, if we want to distinguish between right and wrong, good and evil, just and unjust, we must maintain the notion of moral human rights.

Are there universal human rights? Legal rights are relative to the law and the jurisdiction in a given state and to international law. So, only legal human rights that are conferred by international law and that are common in all legal systems are universal. Moral rights belong, together with moral duties, moral virtues and moral values to moralities. There have been different moralities in history and there are different moralities in our contemporary world. Moralities in Asia differ from moralities in America; moralities in Africa differ from moralities in Europe. In different moralities 
different things are considered as a moral right. Some argue that the rights of the Universal Declaration of Human Rights are not universal at all (Mooij 2012:53-54). Does this mean that there are no common moral rights in all the moralities? If there are no common moral rights, moral rights that are valid in all moralities, then there are no human rights in the strictest sense of the word, rights that every human being has for the one and only reason that he or she is a human being. Then, we can only speak of Asian rights, American rights, African rights and European rights, but not of human rights. A human being would only have the rights of his particular group and morality. To speak about human rights is to speak about human rights people have in all groups and in all moralities. Thus, a truly human right is as such a universal right or it is no human right in the strict sense. But if there would be no moral human rights, there would be no universal difference between right and wrong, good and evil, just and unjust. This is because the notions of moral good and of moral evil both imply the notion of a moral right. When justice is done to you, a right of yours is respected. When you are wronged, a right of yours is violated. If you have the right not to be killed by your neighbour because the colour of your house or because of your convictions, you are wronged when your neighbour kills you because of the colour of your house or because of your convictions. If you would have this right only in particular groups and moralities, there would be groups and moralities where you would not be wronged if you were killed by your neighbour because of the colour of your house or because your conviction. In the end the difference between right and wrong, between just and unjust would be fully arbitrary and relative. It would completely depend on the morality of your group whether something others do to you is right or wrong, just or unjust. This is very implausible. To me, it seems much more likely that killing your neighbour because of the colour of his house or because of his convictions is an action that is judged by all people who suffer from it and by all people who witness it as unjust and wrong. This action is wrong at any time and at any place. Therefore, there are at least some universal moral rights of human beings, human rights tout court. An overlapping consensus about human rights between different moralities is possible (Quinn 2000:68-69).

The right to live is a clear example of a truly human right, that is, a universal right, that is moral and in most societies legal. Other examples are less clear. Is the right to be educated a merely legal right in a given society, or is it also a moral human right? Is the right to work a moral human right? Discussion remains possible and necessary in many cases. In this article, I assume that moral human rights include the right to live, the freedom of conscience, the freedom of speech and the freedom of religion. When I speak in the following sections about human rights, I mean such universal, moral rights. And I will restrict the discussion to the rights people have in relation to each other. Rights and duties in relation to God will only be discussed insofar as they are relevant to the grounding of human rights between humans. The question is whether moral human rights are essentially secular.

\section{Anthropological grounding of human rights: Kant and Cliteur}

In the humanistic tradition of western culture, human rights are anthropologically grounded in human dignity. Kant's account of human dignity, especially in his Grundlegung zur Metaphysik der Sitten (1785), is paradigmatic. Kant explains human dignity by making two distinctions. The first distinction is between end and means. An end of an action can be the means for another action. For Kant, a human being is not only an end that can be used as a means for something else; it is also an end in itself ('Zweck an sich') (Kant 1785:433). The second distinction is between price ('Wert') and dignity ('Würde') by which Kant challenges the view of Hobbes, who said:

The value or worth of a man is, as of all other things, his price; that is to say, so much as would be given for the use of his power. (cited in Wolterstorff 2008:301)

For Kant, worth and price are different categories. The price of something can be more or less and can be compared with the price of other things; the price of something is relative. By contrast, dignity is above all price; human dignity is not relative to the price of other things; it is absolute. Things that have a price are replaceable; human beings that have human dignity are irreplaceable (Kant 1785:434). In summary, for Kant, human beings have human dignity because they have no price and because they are an end in themselves.

For Kant, human beings are not only a means for something else and do not have a price because they are autonomous. It is important to note that the term 'autonomy' has a special meaning in Kant. It does not mean that there is no moral law or principle people have to obey. What it does mean is that the law all human beings have to obey is a law that humankind has given to itself. People give a law to themselves if they act according to moral rules that can be made universal laws, that is, laws without which a human society could not possibly exist. Standard examples of such moral rules in Kant are speaking the truth and keeping promises. These laws are not hypothetical, that is dependent on the will of someone else; they are categorical because they are given by men to themselves. Each human being can give himself and mankind this moral law because he is rational. 'Autonomie ist also der Grund der Würde der menschlichen und jeder vernünftigen Natur' (Kant 1785:436). So in Kant's view, there are moral obligations because of the universal rationality of human reason, not because of the will of God.

In his Kritikder praktischen Vernunft, Kant also stresses that moral obligations are binding because of the autonomy of human reason, not because of God (Kant 1797:125). But here Kant adds something. The ultimate object and end of our moral agency is the highest good in the world (summum bonum), the harmony between morality and beatitude. But human beings are not able to realise the supreme good. Therefore, in order to take the supreme good as possible, we must postulate the existence of God, the cause of nature that guarantees the harmony between morality and happiness. This God is moral; he has intelligence and will (Kant 1797:125, 129). Apparently, for Kant, God is not 
willing in the sense that he is commanding, but he is willing in the sense that he is intending that the highest good be realised by us. The distinction between the commanding and the intending will of God which Kant employs here is well known in reformed scholastic theology. It is important to note that Kant's account of moral obligation only denies God's commanding will. His complete account of morality includes the harmony between obligation and happiness; reference to God and his intending will is an integral part of this account. A closer look reveals that Kant's moral philosophy is humanistic but not 'exclusively anthropological'; it is both anthropological and theistic.

Paul Cliteur follows Kant. But his own view is slightly different from Kant's because he also radicalises and criticises Kant's account. Cliteur radicalises Kant by eliminating the postulation of God in his Kritik der praktischen Vernunft from Kant's moral philosophy because he considers it inconsistent with Kant's strictly secular reasoning in the Grundlegung der Metaphysik der Sitten (Cliteur 2007:263-264). For Cliteur, Kant's fundamental contribution to moral philosophy is his grounding of morality without any reference to God's will; the autonomy of human morality is predominant in Kant's moral philosophy (Cliteur 2004:164, 2007:263, 277, 289). As a consequence, the grounding of human rights in human dignity should be exclusively anthropological.

Cliteur not only radicalises Kant, he also agrees with Schopenhauer's criticism of Kant. According to Schopenhauer, Kant's notion of an 'end in itself' is incoherent. Ends are always relative to a will, because there can only be an end if someone wills that end. Being an end is being wanted (Cliteur 2004:169). In addition, Schopenhauer argues that Kant's understanding of human dignity as absolute worth is incoherent. The worth of something can only be judged in comparison with something else; the notion of worth is essentially relative (Cliteur 2004:170). There can be no absolute worth. Therefore, Schopenhauer rejects Kant's central concept of absolute human dignity. If there is something like human dignity it can only be relative. A corollary of this is that Kant's dichotomy between human beings and other beings such as animals is weakened or even denied (Cliteur 2004:171). Cliteur concludes from Schopenhauer's criticism of Kant that we not only have to respect the dignity or worth of human beings, but also the worth of animals (Cliteur 2004:172).

It is remarkable that Cliteur uses Kant's notion of human dignity in order to argue for an exclusively anthropological, secular grounding of human rights, and at the same time weakens Kant's categorical distinction between the absolute dignity of human beings and the relative worth of animals. It appears that the issues of grounding human rights and of the difference between human animals and non-human animals are closely interconnected. I will not further discuss the relation between human dignity and the worth of animals, but focus on Cliteur's claim that a secular grounding of human rights is the only possible one. In order to assess this claim I use Wolterstorff's (2008) recent book on justice and human rights. Wolterstorff's position is radically opposed to that of Cliteur's. He argues that a secular grounding of human rights is impossible and he proposes a theistic grounding of human rights instead.

\section{Wolterstorff and Kant}

Wolterstorff agrees with Kant that human beings can only have human rights if they have the same unique human worth. But both his grounding and his construal of human dignity differs from Kant's. Kant grounds human dignity on the rational capacity to act according to categorical imperatives. He explains human dignity by construing human beings as ends in themselves who have no price. As far as the first point is concerned, Wolterstorff agrees with Kant. Although he has difficulties with the concept of a human being as an end in itself, because normally we understand by end an event people aim to bring about (Wolterstorff 2008:309), he thinks with Kant that the worth of human beings is non-instrumental (Wolterstorff 2008:310, 321). It is the second point of Kant's construal of human dignity that Wolterstorff criticises: human dignity as absolute. His question to Kant is how worth or dignity can be absolute if it is exclusively based on the rational capacity of man. If worth is based on capacities, Wolterstorff argues, then people with less rational capacities or with malfunctioning rational capacities, such as children with incurable mental damage or elderly people with Alzheimer's disease, must have less worth (Wolterstorff 2008:325-33). Moreover, on the basis of rational capacities no sharp line can be drawn between human and non-human animals (Wolterstorff 2008:332). At this point, Wolterstorff's criticism of Kant converges with Cliteur's. Wolterstorff concludes that Kant's grounding of human rights in human worth cannot work, and he draws a far-reaching conclusion from this: a secular grounding of human rights, for which Kant's account is paradigmatic, is probably bound to fail (Wolterstorff 2008:333, 340). There can only be human dignity, that is, equal worth for all human beings greater than the worth of animals, if this worth is not based on the varying capacities of human beings. If we want to ground human rights on human dignity, we should not look at capacities but elsewhere.

\section{Wolterstorff's theistic grounding of human rights in divine love}

Wolterstorff proposes a theistic grounding of human rights. This attempt is important, especially in secularised and secularising contexts such as West-European culture. If such a grounding of human rights would succeed, a positive connection between God and human rights would have been established. This positive connection would show that the dilemma between God and human rights, advocated in the Dutch public debate by Paul Cliteur, is false. Then, we would not have to choose between God and human rights; we would not need to deny human rights, if we believe in God; we would not need to reject God, if we struggle for human rights. Belief in God and appeal to human rights could go hand in hand perfectly well. They could even reinforce each other. 
So let us have a look at Wolterstorff's theistic grounding of human rights. Wolterstorff thinks that human rights are only possible if human beings have the same non-instrumental worth sufficient to account for human rights and greater than that which any animal has (Wolterstorff 2008:321). Because he thinks it impossible to ground invariable worth on variable capacities, Wolterstorff looks for 'some worth-imparting relation of human beings to God that does not in any way involve a reference to human capacities' (Wolterstorff 2008:352). In an analysis of different kinds of worth, Wolterstorff shows that worth can be bestowed on things. The same goes for the worth of a human person. Someone may acquire worth when she becomes the friend of the queen; she is honoured and envied. If worth can be bestowed on human beings by other human beings, it can also be bestowed on them by God. God can bestow worth on human beings by loving them, by attaching to them. Because God's attachment to them is equal, human beings have the same worth. On the basis of their equal non-intrinsic worth, bestowed on them by God's attachment to them, all human beings have the same inherent human rights, inherent in their worth that is (Wolterstorff 2008:352-360). So the invariable human worth, required for equal inherent human rights, is itself not intrinsic but relational. As Wolterstorff (2008) puts it:

From these reflections I conclude that if God loves a human being with the love of attachment, that love bestows great worth on that human being; other creatures, if they knew about that love, would be envious. And I conclude that if God loves, in the mode of attachment, each and every human being equally and permanently, then natural human rights inhere in the worth bestowed on human beings by that love. Natural human rights are what respect for that worth requires. (p. 360)

I agree with Wolterstorff that human worth or human dignity is a relational notion. I also think that God's special relationship with human beings is ultimately the best ground for human rights. But in my view, his grounding of human rights in God's love raises some serious questions.

The first question concerns Wolterstorff's understanding of God's love. His full account of divine love cannot be discussed here (Wolterstorff 2011), but the theistic description of God's love as attachment that he uses in his grounding of human worth and human rights raises the crucial theological question how we should understand the term attachment when we apply it to God. In a human relationship, it is possible to say that someone can be more or less attached to someone else. But we cannot take it for granted that all the characteristics of human attachment also apply to divine attachment. If we use human attachment as a model in order to describe God's love, we should not only highlight similarities, but also reflect on dissimilarities between human attachment and divine attachment. Is the difference between human attachment and divine attachment only a matter of degree? Is God's attachment the same kind of attachment as human attachment, but then attachment in the highest degree? And if it is, why would God's attachment to human beings be invariable? Wolterstorff presupposes that we can understand divine attachment as degreed or gradable, a matter of more or less. But if we cannot, then we can no longer say that human beings have unique equal worth because of God's equal attachment to each human being that is greater than his attachment to other creatures.

The second question concerns Wolterstorff's view that worth and rights are conferred upon human beings by divine love. There are two problems here. The first one is whether love can bestow rights on someone by giving worth to someone. Are love and rights not categorically different? Vincent Brümmer has pointed out that relationships of love are different from relationships of rights and duties (Brümmer 1993:164-173). In my view, this does not exclude the possibility that a relationship of love between persons is at the same time a relationship of duties and rights or, as I would prefer to call it, 'justified expectations of each other' (Muis 2012:97-98). But such rights and duties of lovers are not created by love as such, but by a promise the lovers give each other in a covenantal relationship. It is not love, but the justice of this covenant of love that creates rights and duties. In the same way, God's relationship of love with humankind can perfectly well be a relationship of justice, as the Old and New Testament witness about God's covenant testifies. But this does not imply that in this covenant it is God's love that bestows rights on human beings; it is his justice that gives rights and duties. Love and justice are different things among human beings, and I think God's love and God's justice are different as well. God's justice cannot be reduced to his love and his love cannot be reduced to his justice. But this identification and this reduction seem inevitable when we ground human rights in divine love.

There is still another problem in Wolterstorff's view that worth and rights are conferred upon human beings by divine love. If I love someone I bestow worth on him, but this is only the worth he has for me, who loves him, or for himself, who is loved by me. In the same way, it can be said that if God loves me he confers worth on me, worth for himself, who loves me, and worth for me, who is loved by him. But Wolterstorff goes further than this. He argues that the love of God for every human being not only bestows worth for God and worth for himself on him, but also worth for every other human being. Why would this be so? Among human beings it is certainly not the case that my being loved by someone gives me worth for everybody else. Why would I have worth for every other human being because I am loved by God? How can the worth that I acquire for God and for myself by being loved by God at the same time be a worth for every other human being? Worth that is conferred and acquired by love is as relational as this love itself. The worth someone acquires by being loved is always worth for the lover or worth of the loved one. Things have no worth without someone for whom they have worth. It seems to me that Wolterstorff overlooks this relational character of worth and treats it as something absolute.

The last question is about Wolterstorff's understanding of human dignity as unique equal worth. For Wolterstorff, 
all human beings have the same worth because God loves them all with the same degree of attachment; human dignity is an invariable worth that is greater than the worth of all other creatures. This means that the difference between the worth of human beings and the worth of other creatures is only a matter of degree. Human worth may in fact not be varying because of God's non-varying equal attachment to all human beings; as such it is not invariable. In this respect, human worth is something relative; it could possibly be more or less; it can be measured in comparison with the worth of other things. At this point, the difference with Kant is striking. For Kant, human dignity as such is absolute, categorically different from price. Human dignity itself is without grades or degrees; a human being cannot be more or less human, cannot have more or less human dignity. The dignity of human beings cannot be compared to the worth of other things. Wolterstorff's notion of human worth is considerably weaker than Kant's notion of human dignity. It must be asked whether his notion of human worth is strong enough to ground human rights.

In my opinion, Wolterstorff's grounding of human rights in divine love does not really succeed because of his understanding of divine love as equal attachment, his confusion of God's love and God's justice, his non-relational construal of human worth, and his understanding of human dignity as relative worth. In particular, his mediating concept of human worth that connects divine love and human rights appears to be problematic. But do we really need the mediating concept of worth in order to ground human rights? Would it not be possible to ground human rights directly? God's love cannot be the ground for human rights because love cannot create rights. Because rights are a matter of justice, it is natural to ask whether human rights can directly be grounded in God's justice.

\section{Theological grounding of human rights in divine justice}

If we try to ground human rights in God's justice, we have to look at central just acts of God from which his just will can be discerned. I conclude this article by sketching briefly some possibilities to ground human rights directly in God's just will, that he has executed and expressed in central just acts, possibilities that might be further explored and spelled out. I prefer to call this grounding of human rights in God's justice theological, rather than theistic or metaphysical, because it fully takes into account central revelatory acts of God in the history of his people and of mankind.

The aim of this article is not to suggest that a theological grounding of human rights is the only possible one. My belief that God's special relationship with human beings is ultimately the best ground for human rights does not a priori exclude all other grounds. Different groundings of human rights may coexist. Human rights can be and have been accepted by people of different moral and religious convictions (Wolterstorff 2008:312). Apparently, moralities and religions can have an overlapping consensus about human rights (Quinn 2000:68-69).

The first divine act that comes to mind as an act of God by which rights are given to human beings, is the act of creation. By creating them, God has given his creatures a right to live. Moreover, he has created mankind in his image, which implies a unique position of men among other creatures and a special relationship between God and humankind (Van Huyssteen 2006:120-121, 160). However, it is hard to specify in what respect human beings imagine God in terms of properties and capacities. Many different interpretations of the image of God have been given in the Christian tradition: substantivist, functional, existential, relational, trinitarian and eschatological interpretations (Van Huyssteen 2006:126158). Therefore, it is difficult, if not impossible, to infer human rights from God's creation of humankind in his image (Wolterstorff 2008:352). Every attempt at doing so remains speculative (Wolterstorff 2008:342, 347). The only thing we can say with certainty is that by creating them in his image God has given human beings a right to live a human life (Bonhoeffer 1998:163-216; Brunner 1943:69-70).

If we would go further than this and would try to infer a set of specific human rights from God's creation of men in his image, we could only do this by interpreting general structures of human society as revelation of the will of God. If we do so, we risk identifying a relative and temporary human status quo in society with God's just will. This identification overlooks the difference between this world, in which human justice and human injustice are mixed, and the coming kingdom of God where justice will prevail. More importantly, it overlooks the difference between divine and human justice. Human justice is different from the justice God has exercised and revealed in his justification of the sinner in Jesus Christ (Jüngel [1968] 2000:252-254; 1998:229-233). It is also different from the justice God will ultimately and fully reveal and realise in his coming kingdom. Therefore we must draw a clear theological distinction between human justice and divine justice. Legal human rights belong to the human justice in this world. They cannot be inferred from scripture or revelation (Scholten [1939] 2010:400, 404).

However, this is not the whole story. There are not only legal human rights that are part of human justice. There are also moral human rights, and some of these moral human rights are universal. The right to live a human life is a universal moral human right. This right not only belongs to human justice. It is a right given by the Creator to all human beings in his act of creation. Because creation implies the giving of a right it is an act of justice. This shows that there can be no total separation of God's justice and human rights. Apparently, God can give rights to all human beings by acting in relation to them. This possibility need not be restricted to the act of creation. Other divine acts in history could give rights to all human beings as well. I suspect we can discern two such acts in the biblical narrative. The first one is God's giving of the Ten Commandments; the second one is his justification of sinful mankind. Let us have a brief look at both of them. 
The Dutch theologian W.H. Velema has convincingly argued that God's giving of the Ten Commandments implies certain human rights (Velema 1980:34-42). His argument can be summarised as follows. In the second part of the Decalogue, God forbids to murder, to commit adultery, to steal, to bear false witness. These divine prohibitions imply obligations towards other human beings. Human beings are obliged to respect the life of others, marriage, the property of others and the truth. Obligations correlate with rights (Van den Beld 2006:120; Wolterstorff 2008:34, 249-260). If no one shall murder you, then you have a right not to be murdered, that is, you have a right to live. If no one shall steal from you, then you have a right not to be stolen from, that is, you have a right to possess. If no one shall bear false witness against you, you have a right not to be lied to, that is, you have a right to be told the truth. I think Velema is basically right. To be sure, there are some serious questions here. Are obligations and correlative rights conferred by the Ten Commandments in the sense that they were created by God's commanding act (Gericke 2009:308; Van den Beld 2006:131-132)? Were there no obligations and rights before this commanding act of God (cf. Wolterstorff 2008)? Do people have these obligations and rights if they do not know the Ten Commandments? In my opinion, these problems can be solved if we concentrate on the theological core meaning of the Ten Commandments and interpret this meaning in the wider context of God's history with mankind and his universal purposes. The story about the Ten Commandments is much more than a story about an isolated act of God in a particular historical context. The Ten Commandments express, proclaim and reveal in a particular form, God's universal just will with regard to his special relationship with all human beings and the relationships between all human beings. Moreover, all people may in some way be aware of the obligations and rights implied by the second part of the Decalogue, not only those who once listened to Moses or those who have read the Bible (cf. Rm 2:14-15). Lastly, in my view, logical implication is more important here than questions about temporal or ontological priority between God's will and Commandments on the one hand and human obligations and rights on the other (questions that are central to the so-called divine command theory). The crucial point is that there can be no divine just will and there can be no divine Commandments with regard to human relationships without human obligations and human rights. If we believe that God wills something with regard to all just human relationships, we must also accept that all human beings have the obligations and correlative rights implied by his will.

There is still another act of God that can be construed as conferring rights on all human beings. This construal is hinted at by Karl Barth in his doctrine of justification. Although the issue of human rights is not the topic of this doctrine, Barth explains, closely following biblical judicial terminology, God's justification of sinful mankind in Jesus Christ in terms of divine and human rights (see Muis 2014:184-187, 192-194). God justifies sinners in Jesus Christ. By the union of Jesus Christ with humankind, all human beings have been adopted as sons and daughters of God. This adoption is a legal act by which God has given all human beings the right to be his children. According to Barth ([1953] 1960), the right to be God's children is the 'essence' or 'totality' of human justice, or human rights:

Ist Gott sein Vater und er dieses Vaters Kind, so ist Gott so wenig ohne ihn Gott, wie er ohne Gott Mensch ist, so hat er Gott gegenüber im gleichen Sinn Kindesrecht, wie Gott ihm gegenüber Vaterrecht hat: das Recht auf sein Sein mit ihm, das Recht auf jederzeitigen Zugang zu ihm, das Recht ihn anzurufen, das Recht sich auf ihn zu verlassen, das Recht, Alles, dessen er bedarf, von ihm zu erwarten und zu erbeten. Dieses Kindesrecht ist der Inbegriff alles Menschenrechtes. (p. 669)

Barth construes God's justification of the sinner in the death and resurrection of Jesus Christ as an act that includes all human beings (cf. Muis 1989:111-112). The death of Jesus Christ is the death of all human beings (2 Cor 5:14; Barth [1953] 1960:324-326). In his resurrection all human beings have been justified (Barth [1953] 1960:37, 38-39). Therefore, God's justification of sinners has a bearing on the condition of all people just as the act of creation and the act of giving the Ten Commandments have.

Barth does not explain why the right to be God's children is the 'Inbegriff' of all human rights. We can spell out this claim as follows. When in justification all people have been given the right to be God's sons and daughters - whether they know and believe this or not - they have thereby become brothers and sisters of each other in Christ. This brotherhood and sisterhood of men is not a natural fact; it is a right given to them by God in the union of Christ with all human beings. Because Jesus Christ is brother of all human beings, all human beings are his brothers and sisters and brothers and sisters of each other. This brotherhood and sisterhood of men is the true basis for all human rights. You have the right not to be killed by me because you are my brother or sister and I am your brother. This basis for human rights is valid in all societies, in all legal systems and in all moralities. Without the brotherhood and sisterhood of men there can be no human rights. Because of our brotherhood and sisterhood in Jesus Christ there are human rights.

\section{Acknowledgements}

I would like to thank G. van den Brink, J. Hoek, C. van der Knijff, R. Reeling Brouwer, E. Willemsen and G. van Zanden for their helpful comments on the first draft of this article.

\section{Competing interests}

The author declares that he has no financial or personal relationship(s) that may have inappropriately influenced him in writing this article.

\section{References}

Barth, K., [1953] 1960, Die Kirchliche Dogmatik, IV/1, Die Lehre von der Versöhnung, EVZ-Verlag, Zürich.

Bonhoeffer, D., 1998, Ethik, Dietrich Bonhoeffer Werke, vol. 6, eds. I. Tödt, H. E. Tödt, E. Feil \& C. Green, Kaiser, München. 
Brague, R., 2013, Le Propre de l'homme: Sur une légitimé menacée, Flammarion, Paris. Brümmer, V., 1993, The model of love: A study in philosophical theology, Cambridge University Press, Cambridge. http://dx.doi.org/10.1017/CBO9780511621277

Brunner, E., 1943, Gerechtigkeit: Eine Lehre von den Grundgesetzen der Gesellschaftsordnung, Zwingli-Verlag, Zürich.

Cliteur, P.B., 2004, 'Human dignity as the foundation for human rights', Rechtstheorie $35,157-173$

Cliteur, P., 2007, Moreel Esperanto: Naar een autonome ethiek, De Arbeiderspers, Amsterdam/Antwerpen.

Cliteur, P.B., 2009, 'Zijn de mensenrechten nog steeds de harde kern van de moderniteit?', Civis Mundi 48, 148-151.

Cliteur, P.B., 2013, 'Theism and human rights', in A.J.L. Menuge (ed.), Legitimizing human rights: Secular and religious perspectives, pp. 33-57, Ashgate, Farnham.

Gericke, J.W., 2009, 'Beyond divine command theory: Moral realism in the Hebrew Bible', HTS Teologiese Studies/Theological Studies 65(1), 5 pages. http://dx.doi. org/10.4102/hts.v65i1.160

Gregory, B.S., 2012, The unintended Reformation: How a religious revolution secularized society, The Belknap Press of Harvard University Press, Cambridge, MA/London.

Jüngel, E., [1968] 2000, 'Freiheitsrechte und Gerechtigkeit', Unterwegs zur Sache. Theologische Erörterungen I, pp. 246-256, Mohr Siebeck, Tübingen.

Jüngel, E., 1998, Das Evangelium von der Rechtfertigung des Gottlosen als Zentrum des christlichen Glaubens: Eine theologische Studie in ökumenischer Absicht, Mohr Siebeck, Tübingen.

Kant, I., 1785, Grundlegung zur Metaphysik der Sitten, Akademie-Ausgabe, Berlin.

Kant, I., 1797, Kritik der praktischen Vernunft, Akademie-Ausgabe, Berlin.

MacIntyre, A., [1981] 1984, After virtue: A study in moral theory, University of Notre Dame Press, Notre Dame, IN.
Mooij, J.J.A., 2012, Het morele domein: Over meervoudigheid in de moraal, Amsterdam Univeristy Press, Amsterdam.

Muis, J., 1989, Openbaring en interpretatie: Het verstaan van de Heilige Schrift volgens K. Barth en K.H. Miskotte, Boekencentrum, 's Gravenhage.

Muis, J., 2012, 'De liefde van God', Nederduitse Gereformeerde Teologiese Tydskrift 53(suppl. 3), 91-99.

Muis, J., 2014, 'Justification and the Justice of God. Barth's view', Zeitschrift für dialektische Theologie, suppl. ser. 6, 177-194.

Quinn, P.L., 2000, 'Divine Command Theory', in H. LaFolette (ed.), The Blackwell guide to ethical theory, pp. 53-73, Blackwell, Oxford.

Schenderling, J., 2010, 'De theologie van de mensenrechten', Kerk en Theologie 61(1), 5-18.

Scholten, P., [1939] 2010, 'Evangelie en recht', in T.J.M. Slootweg (red.), Dorsten naar gerechtigheid, pp. 387-405, Kluwer, Deventer.

Taylor, C., 2007, A secular age, The Belknap Press of Harvard University Press, Cambridg, MA/London.

Van den Beld, T., 2006, 'Human rights, moral obligations, and Divine Commands', Faith and Philosophy 23(2), 119-136. http://dx.doi.org/10.5840/faithphil200623216

Van Huyssteen, J.W., 2006, Alone in the World? Human uniqueness in science and theology, Eerdmans, Grand Rapids, MI.

Velema, W.H., 1980, Discussie over de mensenrechten, Buijten \& Schipperheijn, Amsterdam.

Wolterstorff, N., 2008, Justice: Rights and wrongs, Princeton University Press, Princeton, NJ.

Wolterstorff, N., 2011, Justice in love, Eerdmans, Grand Rapids, MI. 